\title{
Penerapan Metode Forward Chaining dan Naïve Bayes Untuk Mendiagnosa Penyakit Tanaman Kakao
}

\author{
Hilman Hadi, Ucuk Darusalam, Andrianingsih* \\ Fakultas Teknologi Komunikasi dan Infomatika, Prodi Sistem Informasi, Universitas Nasional, Jakarta, Indonesia \\ Email: ${ }^{1}$ hilmanhadi27@gmail.com, ${ }^{2}$ ucuk.darusalam@civitas.unas.ac.id, ${ }^{3,}$ andrianingsih@ \\ Email Penulis Korespondensi: andrianingsih@civitas.unas.ac.id
}

\begin{abstract}
Abstrak-Kakao adalah satu dari sekian banyak hasil perkebunan diIndonesia yang mempunyani nilai ekonomi yang cukup besar, dan memiliki lahan perkebunan serta produksinya tiap tahun mengalami peningkatan yang cukup signifikan. Kurangnya tenaga ahli penyuluh pertanian dalam memberikan pengarahan, pembinaan, dan penyuluhan informasi tentang perkembangan penyakit tanaman kakao yang dihadapi oleh para pembudidaya tanaman tersebut, dapat membawa dampak bagi pembudidayanya. Metode yang dipakai dalam penelitian ini adalah metode forward chaining dan naïve bayes. Sistem ini diharapkan dapat berguna untuk user dalam melakukan pendiagnosaan penyakit kakao secara mandiri, tentu saja dengan mudah dan efisien tanpa harus memerlukan tenaga ahli dibidangnya, dengan mengacu pada hasil dan pembahasan yang dilakukan, tingkat keakuratan dari sistem ini memiliki nilai akurasi sekitar 95\% dalam melakukan pendiagnosaannya.
\end{abstract}

Kata Kunci: Sistem Pakar; Forward Chaining; Naive Bayes; Penyakit Tanaman Kakao; Berbasis Web

\begin{abstract}
Cocoa is one of the many plantation products in Indonesia which has considerable economic value, and has plantation land and its production each year has increased significantly. The lack of agricultural extension experts in providing direction, guidance, and information dissemination about the development of cocoa plant diseases faced by the cultivators of these plants can have an impact on the cultivators. The method used in this research is the forward chaining and naïve Bayes method. This system is expected to be useful for users in diagnosing cocoa diseases independently, of course easily and efficiently without having to require experts in their fields, with reference to the results and discussions carried out, the accuracy of this system has an accuracy value of about $95 \%$ in carrying out the diagnosis.
\end{abstract}

Keywords: Expert System; Forward Chaining; Naïve Bayes; Cocoa Plant Diseases; Web Based

\section{PENDAHULUAN}

Semakin berkembangya teknologi dari hari kehari dimana hal tesebut tentunya memiliki manfaat yang besar bagi dunia usaha, salah satu manfaatnya yaitu digunakan sebagai alat bantu untuk melakukan sesuatu, teknologi komputer dapat dimanfaatkan oleh instansi pemerintah maupun perusahaan untuk memajukan perusahaan mereka masing-masing dengan cara meningkatkan efisiensi dalam pekerjaan setiap individunya[1].

Didunia perbisnisan teknologi sangat diperlukan guna mempermudah suatu pekerjaan, sistem pakar pun juga ikut dalam perkembangannya untuk dipakai dimacam-macam bidang[2], antara lain dalam bidang pangan. Salah satu contoh kegunaan dari sistem pakar dalam bidang pangan adalah mempermudah petani untuk mendeteksi penyakit yang dialami pada tanaman yang dibudidanya[3], sehingga dapat mendeteksi sedini mungkin tentang penyakit yang dialami oleh tanaman tersebut dan juga dapat mengetahui cara mengatasi masalah tersebut dengan cepat dan akurat tanpa harus menunggu lama orang yang ahli dalam bidang tersebut[4].

Ada bermacam-macam hama penyakit yang dapat menjangkiti tanaman kakao tentu saja hal tersebut dapat menimbulkan kerugian bagi pembudidayanya[5], Pengidentifikasian hama penyakit dari tanaman kakao diharuskan secepat mungkin dilakukan secara tepat sasaran dan cepat, apabila tidak penyakit dari tanaman tersebut dapat dengan cepat menjalar ke tanaman lainnya diseluruh area pekebunan[6]. Apabila pembudidaya dapat dengan mudah mendeteksi penyakit tersebut maka akan lebih mudah pula penanganannya, begitu pula sebaliknya apabila pembudidaya terlambat mengetahui masalahdan harus menunggu terlebih seseorang yang ahli dibidang tersebut dapat berakibat fatal[7].

Sistem pakar untuk melakukan pendiagnosaan penyakit dari tanaman kakao ini menggunakan metode forward chaining dan naïve bayes yang dikembangkan berbasis website, dapat digunakan oleh pembudidaya tanaman kakao dan user lainnya secara gratis, dimaksudkan untuk membantu pembudidaya tanaman kakao dalam melakukan pendiagnosaan penyakit tanaman kakao tersebut sehingga dapat mengurangi dampak kerugian yang dialami[8].

Berdasarkan studi referensi yang dilakukan, ada beberapa penelitian terkait penggunaan metode naïve bayes untuk mendiagnosa penyakit berbagai tanaman antara lain penelitian yang dilakukan oleh Ahmad Syarifudin dkk ditahun 2018. Penelitian tersebut tentang pendiagnosaan penyakit tanaman jagung menggunakan teori naïve bayes yang menghasilkan tingkat akurasi sistem sebesar 96\%[9]. Penelitian selanjutnya yang dilakukan oleh Ali Syahrawardi dkk ditahun 2018, penelitian tersebut membahas pendiagnosaan hama penyakit tanaman sedap malam mengunakan metode naïve bayes dan memiliki tingkat keakuratan sebesar 86,67\%[10]. Penelitian ketiga yang dilakukan oleh Mohammad Syarif dkk yang dilakukan pada tahun 2017, yaitu mendeteksi penyakit tanaman jagung pula memiliki hasil kecocokan sebesar 18 dari 30 kasus percobaan yang dilakukan[11]. Selanjutnya ada penelitian Acihmah dkk pada tahun 2017, disitu tertulis bahwa tingkat keakuratan dari aplikasi yang dibuat sekitar 92,25\% untuk mendeteksi penyakit dari tanaman tanaman kelapa sawit[12]. Kemudian ke 
penelitian selanjutnya tentang pendiagnosaan tanaman cengkeh yang dilakukan oleh Adrianto Setiawan tahun 2018, hasil yang didapatkan dari pengujian tersebut akurasi sistem sekitar 93\%[13]. Terakhir, ada penilitian dari Paul Manason tahun 2018, tentang diagnosa penyakit gigi dengan menggunakan 30 data uji ia memperoleh sekitar 93,3\% tingkat akurasi[14]. Berdasarkan tinjauan penelitian tersebut, penelitian ini juga diharapkan dapat berguna untuk user dalam melakukan pendiagnosaan penyakit kakao secara mandiri, tentu saja dengan mudah dan efisien tanpa harus memerlukan tenaga ahli dibidangnya[15].

\section{METODOLOGI PENELITIAN}

\subsection{Tahapan Penelitian}

a. Melakukan Perencanaan

Ini merupakan tahap awal yang dilakukan dalam penelitian, hal yang dilakukan yaitu mencari dan mengidentifikasi masalah yang akan diteliti.

b. Pengumpulan Data

Pada tahap ini dilakukan studi kepustakaan, yaitu merupakan salah satu teknik pengumpulan data dengan mencari teori-teori yang telah dikembangkan dalam bidang ilmu yang berhubungan dengan pembuatan aplikasi serta melakukan referensi dengan buku-buku yang berkaitan dengan masalah yang diangkat dan eksplorasi internet, yaitu dengan cara membuka situs-situs yang berhubungan dengan tema yang diangkat dalam penelitian ini serta mencari jurnal-jurnal refrensi yang berhubungan dengan penelitian ini.

c. Melakukan Implementasi

Melakukan penghitungan dan menerapkan metode yang dipakai kedalam aplikasi yang dibuat.

\subsection{Sistem Pakar}

Definisi Sistem pakar itu sendiri murupakan suatu sistem program komputer yang memilki ilmu pengetahuan dari satu atau beberapa pakar dalam bidangnya masing-masing. Sistem pakar adalah satu dari sekian banyak cabang Artificial Intelligence (AI), sistem pakar menggunakan pengetahuan yang dimiliki pakar dan dimasukkan ke dalam komputer untuk membantu orang yang tidak memiliki kompetensi dibidangnya dalam melakukan suatu kegiatan agar mempermudah orang tersebut tanpa memerlukan seorang tenaga ahli[16].

\subsection{Forward Chaining}

Metode Forward Chaining adalah suatu metode pencarian/penarikan kesimpulan berdasarkan data atau fakta yang ada, pencarian dimulai dari fakta-fakta yang ada, kemudian bergerak maju melalui premis-premis untuk menarik kesimpulan. Maka dari itu sistem kerja dari metode tersebut yaitu memberikan suatu informasi yang bisa disebut [IF] dan memperoleh hasil yang diinginkan atau disebut [THEN][17].

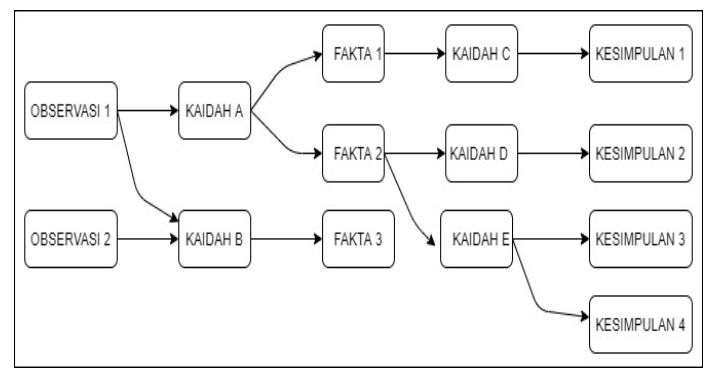

Gambar 1. Proses Forward Chaining

Gambar di atas merupakan alur bagaimana terjadinya proses dari metode forward chaining mulai dari obeservasi hingga didapatkannya kesimpulan.

\subsection{Naïve Bayes}

Metode Naive Bayes adalah metode untuk menghitung peluang terjadinya suatu peristiwa berdasarkan efek yang diperoleh dari pengamatan. Probabilitas Bayes adalah metode menggunakan rumus formula Bayes untuk mengatasi ketidakpastian data[16], yang dinyatakan sebagai:

Dimana:

$$
P(H \mid E)=\frac{P(E \mid H) * P(H)}{P(E)}
$$

$\mathrm{H} \quad$ : hipótesis data

E : data class yang belum diketahui

$\mathrm{P}(\mathrm{H} \mid \mathrm{E})$ : probabilitas hipotesis $\mathrm{H}$ atas kondisi evidence $\mathrm{E}$.

$\mathrm{P}(\mathrm{E} \mid \mathrm{H})$ : probabilitas munculnya nilai evidence $\mathrm{E}$ apabila hipótesis $\mathrm{H}$ diketahui. 
JURNAL MEDIA INFORMATIKA BUDIDARMA

Volume 5, Nomor 3, Juli 2021, Page 979-986

ISSN 2614-5278 (media cetak), ISSN 2548-8368 (media online)

Available Online at https://ejurnal.stmik-budidarma.ac.id/index.php/mib

DOI 10.30865/mib.v5i3.3096

$\mathrm{P}(\mathrm{H}) \quad$ : probabilitas hipótesis $\mathrm{H}$ tanpa mengandung evidence apapun,

$\mathrm{P}(\mathrm{E}) \quad$ : probabilitas dari evidence $\mathrm{E}$.

\section{HASIL DAN PEMBAHASAN}

\subsection{Basis Pengetahuan}

Bedasarkan data dari buku saku Hama dan Penyakit Tanaman Kakao Direktorat Perlindungan dan Direktorat Jendral Pertanian tahun 2019 berikut adalah daftar dari penyakit dan hama yang terdapat pada tanaman kakao.

Tabel 1. Penyakit Pada Tanaman Kakao

\begin{tabular}{|c|c|}
\hline $\begin{array}{c}\text { Kode } \\
\text { Penyakit }\end{array}$ & Nama Penyakit \\
\hline P1 & Penggerek Buah Kakao/PBK \\
\hline $\mathrm{P} 2$ & Kepik Penghisap Buah \\
\hline P3 & Penggerek Cabang \\
\hline P4 & Ulat Kilan \\
\hline P5 & Kumbang Daun \\
\hline P6 & Tikus dan Tupai \\
\hline P7 & Busuk Buah \\
\hline P8 & Vascular Streak Dieback/VSD \\
\hline P9 & Kanker Batang \\
\hline P10 & Antraknosa \\
\hline P11 & Penyakit Akar \\
\hline
\end{tabular}

Bedasarkan tabel 1 diatas terdapat 11 penyakit dan hama pada tanaman kakao yaitu, Penggerek Buah Kakao, Kepik Penghisap Buah, Penggerek Cabang, Ulat Kilan, Kumbang Daun, Tikus dan Tupai, Busuk Buah, Vascular Streak Dieback, Kanker Batang, Antraknosa dan Penyakit akar.

Tabel 2. Gejala Penyakit Tanaman Kakao

\begin{tabular}{cc}
\hline Kode & Gejala Penyakit \\
Gejala & Warna Buah Tidak Merata \\
KG1 & Biji Tidak Terbentuk Sempurna \\
KG2 & Biji Berukuran Kecil \\
KG3 & Buah Bercak Coklat \\
KG4 & Buah Kering \\
KG5 & Kulit Buah Retak \\
KG6 & Pucuk Layu dan Mati \\
KG7 & Ranting Mengering \\
KG8 & Cabang Berlubang \\
KG9 & Daun Berlubang \\
KG10 & Tanaman Gundul \\
KG11 & Pucuk Berlubang \\
KG12 & Buah Berlubang \\
KG13 & Buah Busuk Basah \\
KG14 & Buah Muncul Serbuk Putih \\
KG15 & Tanaman Meranting \\
KG16 & Daun Menguning \\
KG17 & Aardapat Rongga Gerekan \\
KG18 & Audukan Daun Berwarna Coklat \\
KG19 & Kulit Batang Hitam Membusuk \\
KG20 & Bintik Nekrosis Pada Daun Muda \\
KG21 & Matinya Seluruh Jaringan Daun \\
KG22 & Akar Membusuk \\
KG23 &
\end{tabular}

Berdasarkan tabel 2 terdapat 24 gejala yang terdapat pada penyakit tanaman kakao yang sering muncul atau terjadi menurut pakar/ahli. 
JURNAL MEDIA INFORMATIKA BUDIDARMA

Volume 5, Nomor 3, Juli 2021, Page 979-986

ISSN 2614-5278 (media cetak), ISSN 2548-8368 (media online)

Available Online at https://ejurnal.stmik-budidarma.ac.id/index.php/mib

DOI 10.30865/mib.v5i3.3096

Tabel 3. Data Aturan Sistem

\begin{tabular}{ccc}
\hline $\begin{array}{c}\text { Kode } \\
\text { Penyakit }\end{array}$ & Nama Penyakit & $\begin{array}{c}\text { Kode } \\
\text { Gejala }\end{array}$ \\
\hline P1 & Penggerek Buah Kakao/PBK & KG1,KG2,KG3 \\
P2 & Kepik Penghisap Buah & KG4,KG5,KG6,KG7,KG8 \\
P3 & Penggerek Cabang & KG9,KG10 \\
P4 & Ulat Kilan & KG11,KG12 \\
P5 & Kumbang Daun & KG7,KG13 \\
P6 & Tikus dan Tupai & KG14 \\
P7 & Busuk Buah & KG15,KG16 \\
P8 & Vascular Streak Dieback/VSD & KG17,KG18,KG19 \\
P9 & Kanker Batang & KG20 \\
P10 & Antraknosa & KG4,KG12,KG21,KG22 \\
P11 & Penyakit Akar & KG18,KG23,KG24 \\
\hline
\end{tabular}

\subsection{Proses Penghitungan Menggunakan Metode Naïve Bayes}

Untuk penghitungan ini mengambil contoh dari salah satu penyakit pada tanaman kakao yaitu penggerek buah kakao.

Tabel 4. Gejala yang dialami Penyakit Penggerek Buah Kakao

\begin{tabular}{ccc}
\hline Kode Gejala & Gejala Penyakit & Gejala Dialami \\
\hline KG1 & Warna Buah Tidak Merata & Ya \\
KG2 & Biji Tidak Terbentuk Sempurna & Ya \\
KG3 & Biji Berukuran Kecil & Ya \\
KG4 & Buah Bercak Coklat & Tidak \\
KG5 & Buan Kering & Tidak \\
KG6 & Kulit Buah Retak & Tidak \\
KG7 & Pucuk Layu dan Mati & Tidak \\
KG8 & Ranting Mengering & Tidak \\
KG9 & Cabang Berlubang & Tidak \\
KG10 & Cabang Terdapat Rongga Gerekan & Tidak \\
KG11 & Daun Berlubang & Tidak \\
KG12 & Tanaman Gundul & Tidak \\
KG13 & Pucuk Berlubang & Tidak \\
KG14 & Buah Berlubang & Tidak \\
KG15 & Buah Busuk Basah & Tidak \\
KG16 & Buah Muncul Serbuk Putih & Tidak \\
KG17 & Tanaman Meranting & Tidak \\
KG18 & Daun Menguning & Tidak \\
KG19 & Dudukan Daun Berwarna Coklat & Tidak \\
KG20 & Kulit Batang Hitam Membusuk & Tidak \\
KG21 & Bintik Nekrosis Pada Daun Muda & Tidak \\
KG22 & Matinya Seluruh Jaringan Daun & Tidak \\
KG23 & Akar Membusuk & Tidak \\
KG24 & Akar Terdapat Benang Putih & Tidak \\
\hline & & \\
\hline
\end{tabular}

Berdasarkan tabel 4 di atas dapat diketahui gejala apa saja yang terdapat pada penyakit Penggerek Buah Kakao.

Tabel 5. Penghitungan Jumlah dari Masing-masing Class

\begin{tabular}{cl}
\hline No. & \multicolumn{1}{c}{ Jumlah Class Penyakit } \\
\hline 1 & $(\mathrm{E}=$ Penggerek Buah Kakao $)=6 / 56=0,107$ \\
2 & $(\mathrm{E}=$ Kepik Penghisap Buah $)=8 / 56=0,142$ \\
3 & $(\mathrm{E}=$ Penggerek Cabang $)=4 / 56=0,071$ \\
4 & $(\mathrm{E}=$ Ulat Kilan $)=4 / 56=0,071$ \\
5 & $(\mathrm{E}=$ Kumbang Daun $)=4 / 56=0,071$ \\
6 & $(\mathrm{E}=$ Tikus dan Tupai $)=3 / 56=0,053$ \\
7 & $(\mathrm{E}=$ Busuk Buah $)=4 / 56=0,071$ \\
8 & $(\mathrm{E}=$ Vascular Streak Dieback $)=6 / 56=0,107$ \\
9 & $(\mathrm{E}=$ Kanker Batang $)=3 / 56=0,053$ \\
10 & $(\mathrm{E}=$ Antraknosa $)=8 / 56=0,142$ \\
11 & $(\mathrm{E}=$ Penyakit Akar $)=6 / 56=0,107$ \\
\hline
\end{tabular}


Tabel 6. Penghitungan $\mathrm{P}(\mathrm{H} \mid \mathrm{E})$ untuk gejala Penggerek Buah Kakao

\begin{tabular}{|c|c|}
\hline Hitung & Perhitungan Probabilitas Penggerek Buah Kakao \\
\hline KG1 & $\begin{array}{l}(\mathrm{KG} 1=\mathrm{Ya} \mid \mathrm{E})=\text { Penggerek Buah Kakao })=4 / 6=0,666 \\
(\mathrm{KG} 1=\mathrm{Ya} \mid \mathrm{E})=\text { Kepik Penghisap Buah })=5 / 8=0,625 \\
(\mathrm{KG} 1=\mathrm{Ya} \mid \mathrm{E})=\text { Penggerek Cabang })=3 / 4=0,75 \\
(\mathrm{KG} 1=\mathrm{Ya} \mid \mathrm{E})=\text { Ulat Kilan })=1 / 4=0,25 \\
(\mathrm{KG} 1=\mathrm{Ya} \mid \mathrm{E})=\text { Kumbang Daun })=2 / 4=0,5 \\
(\mathrm{KG} 1=\mathrm{Ya} \mid \mathrm{E})=\text { Tikus dan Tupai })=1 / 3=0,333 \\
(\mathrm{KG} 1=\mathrm{Ya} \mid \mathrm{E})=\text { Busuk Buah })=3 / 4=0,75 \\
(\mathrm{KG} 1=\mathrm{Ya} \mid \mathrm{E})=\text { Vascular Streak Dieback })=5 / 6=0,833 \\
(\mathrm{KG} 1=\mathrm{Ya} \mid \mathrm{E})=\text { Kanker Batang })=2 / 3=0,666 \\
(\mathrm{KG} 1=\mathrm{Ya} \mid \mathrm{E})=\text { Antraknosa })=7 / 8=0,875 \\
(\mathrm{KG} 1=\mathrm{Ya} \mid \mathrm{E})=\text { Penyakit Akar })=2 / 6=0,333\end{array}$ \\
\hline KG2 & $\begin{array}{l}(\mathrm{KG} 2=\mathrm{Ya} \mid \mathrm{E})=\text { Penggerek Buah Kakao })=4 / 6=0,666 \\
(\mathrm{KG} 2=\mathrm{Ya} \mid \mathrm{E})=\text { Kepik Penghisap Buah })=5 / 8=0,625 \\
(\mathrm{KG} 2=\mathrm{Ya} \mid \mathrm{E})=\text { Penggerek Cabang })=3 / 4=0,75 \\
(\mathrm{KG} 2=\mathrm{Ya} \mid \mathrm{E})=\text { Ulat Kilan })=1 / 4=0,25 \\
(\mathrm{KG} 2=\mathrm{Ya} \mid \mathrm{E})=\text { Kumbang Daun })=2 / 4=0,5 \\
(\mathrm{KG} 2=\mathrm{Ya} \mid \mathrm{E})=\text { Tikus dan Tupai })=1 / 3=0,333 \\
(\mathrm{KG} 2=\mathrm{Ya} \mid \mathrm{E})=\text { Busuk Buah })=3 / 4=0,75 \\
(\mathrm{KG} 2=\mathrm{Ya} \mid \mathrm{E})=\text { Vascular Streak Dieback })=5 / 6=0,833 \\
(\mathrm{KG} 2=\mathrm{Ya} \mid \mathrm{E})=\text { Kanker Batang })=2 / 3=0,666 \\
(\mathrm{KG} 2=\mathrm{Ya} \mid \mathrm{E})=\text { Antraknosa })=7 / 8=0,875 \\
(\mathrm{KG} 2=\mathrm{Ya} \mid \mathrm{E})=\text { Penyakit Akar })=2 / 6=0,333\end{array}$ \\
\hline KG3 & $\begin{array}{l}(\mathrm{KG} 3=\mathrm{Ya} \mid \mathrm{E})=\text { Penggerek Buah Kakao })=4 / 6=0,666 \\
(\mathrm{KG} 3=\mathrm{Ya} \mid \mathrm{E})=\text { Kepik Penghisap Buah })=5 / 8=0,625 \\
(\mathrm{KG} 3=\mathrm{Ya} \mid \mathrm{E})=\text { Penggerek Cabang })=3 / 4=0,75 \\
(\mathrm{KG} 3=\mathrm{Ya} \mid \mathrm{E})=\text { Ulat Kilan })=1 / 4=0,25 \\
(\mathrm{KG} 3=\mathrm{Ya} \mid \mathrm{E})=\text { Kumbang Daun })=2 / 4=0,5 \\
(\mathrm{KG} 3=\mathrm{Ya} \mid \mathrm{E})=\text { Tikus dan Tupai })=1 / 3=0,333 \\
(\mathrm{KG} 3=\mathrm{Ya} \mid \mathrm{E})=\text { Busuk Buah })=3 / 4=0,75 \\
(\mathrm{KG} 3=\mathrm{Ya} \mid \mathrm{E})=\text { Vascular Streak Dieback })=5 / 6=0,833 \\
(\mathrm{KG} 3=\mathrm{Ya} \mid \mathrm{E})=\text { Kanker Batang })=2 / 3=0,666 \\
(\mathrm{KG} 3=\mathrm{Ya} \mid \mathrm{E})=\text { Antraknosa })=7 / 8=0,875 \\
(\mathrm{KG} 3=\mathrm{Ya} \mid \mathrm{E})=\text { Penyakit Akar })=2 / 6=0,333\end{array}$ \\
\hline
\end{tabular}

Berdasarkan tabel 6 diatas dijelaskan perhitungan gejala penyakit Penggerek Buah Kakao dengan hipotesis dan menghasilkan nilai probabilitas dari class penyakit Penggerek Buah Kakao dari gejala yang dialami.

\subsection{Perhitungan Manual Metode Naïve Bayes}

Percobaan hitung $\mathrm{P}(\mathrm{P} 1 \mid \mathrm{KG} 1)$, sebagai berikut:

$$
\begin{aligned}
& P(P 1 \mid K G 1)=\frac{0,666 * 0,107}{(0,666 * 0,107)+(0,625 * 0,142)+} \\
& (0,75 * 0,071)+(0,25 * 0,071)+(0,5 * 0,071)+ \\
& (0,333 * 0,053)+(0,75 * 0,071)+ \\
& (0,833 * 0,107)+(0,666 * 0,053)+(0,875 * 0,142)+ \\
& (0,333 * 0,107) \\
& P(P 1 \mid K G 1)=0,115
\end{aligned}
$$

\subsection{Perbandingan Hasil Implementasi}

Berikut adalah hasil perbandingan implementasi dari 2 metode yaitu forward chaining dan naïve bayes.

Tabel 6. Perbandingan metode

\begin{tabular}{ccccc}
\hline No. & Kode Gejala & Forward Chaining & Naïve Bayes & Hasil \\
\hline 1 & KG1,KG2,KG3,K & Penggerek Buah Kakao & Penggerek Buah Kakao & Benar \\
& G4 & & & \\
2 & KG1,KG2,KG3 & Penggerek Buah Kakao & Penggerek Buah Kakao & Benar \\
3 & KG4,KG5,KG6,K & Kepik Penghisap Buah & Kepik Penghisap Buah & Benar \\
\hline
\end{tabular}


JURNAL MEDIA INFORMATIKA BUDIDARMA

Volume 5, Nomor 3, Juli 2021, Page 979-986

ISSN 2614-5278 (media cetak), ISSN 2548-8368 (media online)

Available Online at https://ejurnal.stmik-budidarma.ac.id/index.php/mib DOI 10.30865/mib.v5i3.3096

\begin{tabular}{|c|c|c|c|c|}
\hline No. & Kode Gejala & Forward Chaining & Naïve Bayes & Hasil \\
\hline & G7,KG8 & & & \\
\hline 4 & KG4,KG5,KG6 & Kepik Penghisap Buah & Kepik Penghisap Buah & Benar \\
\hline 5 & KG9,KG10 & Penggerek Cabang & Penggerek Cabang & Benar \\
\hline 6 & KG9,KG10,KG11 & Penggerek Cabang & Penggerek Cabang & Benar \\
\hline 7 & KG11,KG12 & Ulat Kilan & Ulat Kilan & Benar \\
\hline 8 & KG7,KG13 & Kumbang Daun & Kumbang Daun & Benar \\
\hline 9 & KG13 & Kumbang Daun & Kumbang Daun & Benar \\
\hline 10 & KG14 & Tikus dan Tupai & Penggerek Buah Kakao & Salah \\
\hline 11 & KG15,KG16 & Busuk Buah & Busuk Buah & Benar \\
\hline 12 & $\begin{array}{c}\mathrm{KG} 15, \mathrm{KG} 16, \mathrm{KG} 1 \\
7\end{array}$ & Busuk Buah & Busuk Buah & Benar \\
\hline 13 & $\begin{array}{c}\mathrm{KG} 17, \mathrm{KG} 18, \mathrm{KG} 1 \\
9\end{array}$ & Vascular Streak Dieback & $\begin{array}{c}\text { Vascular Streak } \\
\text { Dieback }\end{array}$ & Benar \\
\hline 14 & KG17,KG18 & Vascular Streak Dieback & $\begin{array}{c}\text { Vascular Streak } \\
\text { Dieback }\end{array}$ & Benar \\
\hline 15 & KG20 & Kanker Batang & Kanker Batang & Benar \\
\hline 16 & KG20,KG21 & Kanker Batang & Kanker Batang & Benar \\
\hline 17 & $\underset{2}{\mathrm{KG} 12, \mathrm{KG} 21, \mathrm{KG} 2}$ & Antraknosa & Antraknosa & Benar \\
\hline 18 & $\begin{array}{c}\mathrm{KG} 4, \mathrm{KG} 12, \mathrm{KG} 21 \\
, \mathrm{KG} 22\end{array}$ & Antraknosa & Antraknosa & Benar \\
\hline 19 & $\underset{4}{\mathrm{KG} 18, \mathrm{KG} 23, \mathrm{KG} 2}$ & Penyakit Akar & Penyakit Akar & Benar \\
\hline 20 & KG23,KG24 & Penyakit Akar & Penyakit Akar & Benar \\
\hline
\end{tabular}

Berdasarkan dari hasil pengujian diatas dengan melakukan 20 kali tes pengujian, Tingkat keakuratan perbandingan dari 2 metode tersebut yaitu mendapatkan 19 hasil yang sama, maka dari itu nilai akurasinya sekitar:

$$
\begin{aligned}
& \text { Nilai Akurasi }=\frac{19}{20} \times 100 \\
& \text { Maka Nilai Akurasi }=95 \%
\end{aligned}
$$

\subsection{Tampilan User Interface}

Gambar ini merupakan tampilan awal aplikasi diagnose penyakit kakao terdapat menu home dan mulai diagnosa.

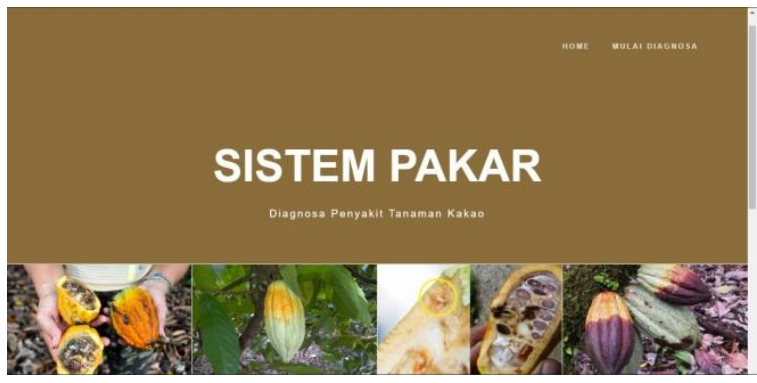

Gambar 2. Tampilan Menu Home

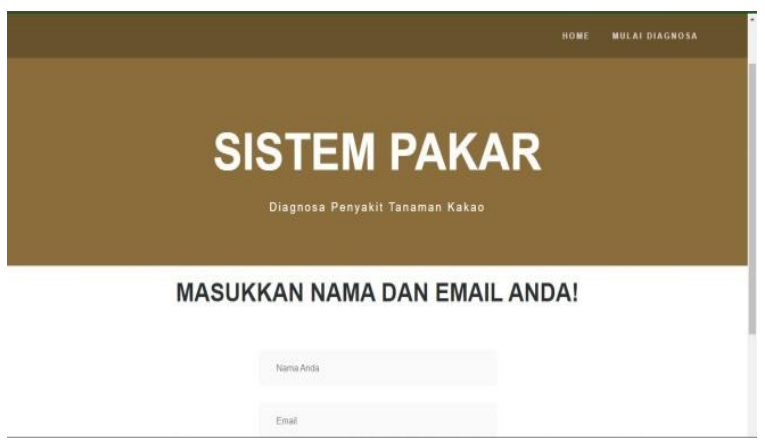

Gambar 3. Tampilan Menu Mulai Diagnosa

Berdasarkan gambar diatas merupakan menu mulai diagnosa, apabila ingin melakukan diagnosa harus memasukkan nama beserta email. 


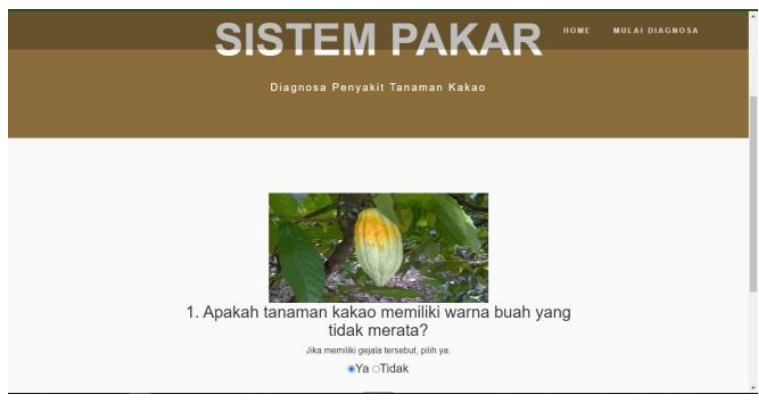

Gambar 4. Tampilan Pemilihan Gejala Penyakit

Gambar di atas terdapat tampilan salah satu pertanyaan yang muncul saat kita melakukan diagnosa penyakit tanaman kakao.

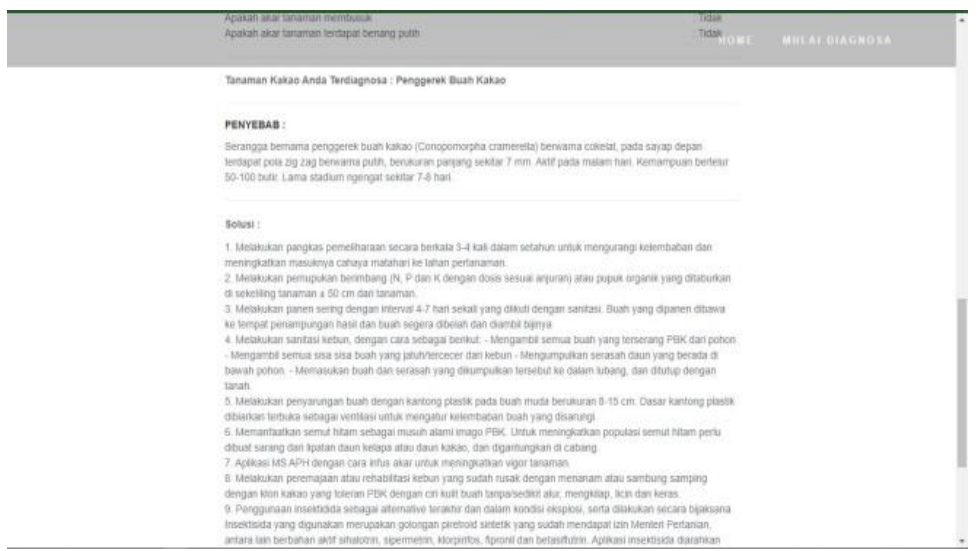

Gambar 4. Tampilan Hasil Diagnosa

Berdasarkan gambar di atas, menunjukkan tampilan hasil diagnosa penyakit yang muncul setelah pertanyaan selesai dijawab.

\section{KESIMPULAN}

Mengacu pada hasil dan pembahasan serta perhitungan diatas, maka dapat diberi kesimpulan bahwa aplikasi diagnosa penyakit tanaman kakao dengan mengunakan metode forward chaining dan naïve bayes yang begitu sederhana ini dapat membantu user dalam melakukan pendiagnosaan penyakit pada tanaman kakao dan juga dapat mengetahui penyebab serta solusi dari penyakit tersebut secara mudah dan efisien dengan tingkat akurasi sekitar $95 \%$.

\section{UCAPAN TERIMAKASIH}

Terima kasih disampaikan kepada pihak-pihak yang telah mendukung terlaksananya penelitian ini terutama untuk dosen pembimbing 1 dan dosen pembimbing 2 dan juga kepada Tuhan YME sehingga peneletian ini dapat selesai sesuai dengan yang diharapkan.

\section{REFERENCES}

[1] Lasmiati, "SISTEM PAKAR DIAGNOSA PENYAKIT TANAMAN KAKAO MENGGUNAKAN METODE FORWARD CHAINING BERBASIS ANDROID," J. Perencanaan, Sains, Teknol. dan Komput., vol. 3, no. 2, pp. 532-538.

[2] O. Pahlevi and M. K. Atmojo, "Application of Expert System for Diagnosing Diseases Cocoa Plants Using the Forward Chaining Algorithm Method," SinkrOn, vol. 4, no. 2, p. 10, 2020, doi: 10.33395/sinkron.v4i2.10481.

[3] V. Ariandi, H. Kurnia, Heriyanto, and H. Marry, "Expert system for disease diagnosis in cocoa plant using androidbased forward chaining method," J. Phys. Conf. Ser., vol. 1339, no. 1, pp. 0-7, 2019, doi: 10.1088/17426596/1339/1/012009.

[4] A. Franz, "Expert System for Diagnosing Diseases Cocoa Using the Dempster Shafer Method," Tepian, vol. 1, no. 1, pp. 35-43, 2020.

[5] S. Alim, P. P. Lestari, and R. Rusliyawati, "Sistem Pakar Diagnosa Penyakit Tanaman Kakao Menggunakan Metode Certainty Factor Pada Kelompok Tani Pt Olam Indonesia (Cocoa) Cabang Lampung," J. Data Min. dan Sist. Inf., vol. 1, no. 1, p. 26, 2020, doi: 10.33365/jdmsi.v1i1.798.

[6] R. Sulaehani, "Sistem Pakar Diagnosa Penyakit Tanaman Kakao Menggunakan Metode Case Base Reasoning (Cbr) 
Pada Kelompok Tani Gapoktan Desa Makarti Jaya,” Simtek J. Sist. Inf. dan Tek. Komput., vol. 4, no. 1, pp. 74-83, 2019, doi: 10.51876/simtek.v4i1.51.

[7] G. A. Rianty and Taufiq, "Sistem Pakar Diagnosa Penyakit Tanaman Kakao Dengan Metode Breadth First Search," 2016.

[8] S. Hawa, Abdullah, and Usman, "Sistem Pakar Diagnosa Penyakit Pada Tanaman Kakao Menggunakan Metode Forward Chaining (Studi Kasus Dinas Perkebunan Indragiri Hilir)," Sistemasi, vol. 4, no. 2, pp. 1-8, 2015.

[9] A. Syarifudin et al., "Sistem Pakar Diagnosis Penyakit Pada Tanaman Jagung Menggunakan Metode Naive Bayes Berbasis Android," Semesta Tek., vol. 21, no. 2, pp. 1492-1500, 2018.

[10] A. Syahrawardi, N. Hidayat, and D. Sihombing, "Sistem Pakar Diagnosis Hama-Penyakit Pada Tanaman Sedap Malam Menggunakan Metode Naïve Bayes-Certainty Factor Berbasis Android," J. Pengemb. Teknol. Inf. dan Ilmu Komput., vol. 2, no. 1, pp. 153-160, 2018.

[11] M. Syarief, A. Mukminin, N. Prastiti, and W. Setiawan, "Penerapan Metode Naïve Bayes Classifier Untuk," Nero, vol. 3, no. 1, pp. 61-68, 2017.

[12] A. P. Acihmah Sidauruk, "SISTEM PAKAR DIAGNOSA PENYAKIT TANAMAN KELAPA SAWIT MENGGUNAKAN TEOREMA BAYES,” J. Ilm. DASI, vol. 18, no. 1, pp. 51-56, 2017.

[13] A. Setiawan, N. Hidayat, and R. K. Dewi, "Sistem Pakar Diagnosis Penyakit Tanaman Cengkeh Menggunakan Metode Naive Bayes," Pengemb. Teknol. Inf. dan Ilmu Komput., vol. 2, no. 10, pp. 4034-4038, 2018.

[14] P. M. S. Simanjuntak, E. Santoso, and Tibyani, "Sistem Pakar Diagnosa Penyakit Gigi dan Mulut Menggunakan Metode Naive Bayes - Weighted Product," J. Pengemb. Teknol. Inf. dan Ilmu Komput., vol. 2, no. 12, pp. 6952-6958, 2018.

[15] V. P. Dewa, A. Pujianto, and M. H. Putra, "Sistem Pakar Diagnosa Penyakit Buah Nanas Menggunakan Algoritma Bayes Berbasis Web,” Semin. Nas. Teknol. Inf. dan Multimed. 2017, pp. 43-48, 2017.

[16] N. A. Umayah Indah Fitri; Maharani, Septya, "Sistem Pakar Untuk Mendiagnosa Penyakit Pada Tanaman Kakao Menggunakan Metode Teorema Bayes," Pros. SAKTI (Seminar Ilmu Komput. dan Teknol. Informasi), vol. 3, no. 2, pp. 72-75, 2018, [Online]. Available: http://e-journals.unmul.ac.id/index.php/SAKTI/article/view/1839.

[17] A. T. Sumpala and M. N. Sutoyo, "Sistem Pakar Untuk Mendiagnosa Hama Penyakit Tanaman Padi Menggunakan Metode Forward Chaining Dan Certainty Factor," Prosding Semin. Nas., no. November, pp. 261-267, 2018. 